\title{
Bank Restructuring-International Perspectives and Vietnam Practices
}

\author{
Nguyen Hong Son ${ }^{1}$, Tran Thi Thanh $\mathrm{Tu}^{1} \&$ Tran Thi Hoang Yen ${ }^{1}$ \\ ${ }^{1}$ VNU University of Economics and Business, Viet Nam \\ Correspondence: Tran Thi Hoang Yen, VNU University of Economics and Business, Viet Nam. E-mail: \\ yentth@vnu.edu.vn
}

Received: February 24, 2014

Accepted: March 13, 2014

Online Published: March 14, 2014

doi:10.5430/afr.v3n2p36

URL: http://dx.doi.org/10.5430/afr.v3n2p36

\begin{abstract}
This paper aims at studying the restructuring of commercial banks which has been started since 2011 in Vietnam. This is considered as an active approach in restructuring the banking system in order to effectively obtain targets in the circumstance of no risk of severe crisis or recession. The paper summarizes the international practices and experiences in bank restructuring including: (i) the concept and goals of restructuring, (ii) the circumstances and conditions of the banking system before the restructuring, (iii) the methods and implementation of restructuring, and (iv) the evaluation of the effectiveness of restructuring. By conducting a survey for bank managers, experts, policy makers and researchers, the authors show that there are still uncovered issues for policy makers currently in Vietnam bank restructure such as: which model of restructuring should be applied to Vietnamese banking system, where to get the resources to implement the restructuring, or what is the role of Debt and Asset Trading Corporation (DATC) and coordination among related parties in the restructuring.
\end{abstract}

Keywords: Restructuring, Banking system, Restructuring measures

\section{Introduction}

Through out nearly 25 years since Reformation (DoiMoi), Vietnam's banking system has changed fundamentally along with the economy, contributing an important part in the socio-economic development of the country. However, Vietnam economy has shown several weaknesses in the pursuit of macroeconomic stability, sustainable economic growth, industrialization and modernization, while there are more and more challenges resulting from Vietnam's financial liberalization and international economic integration, especially after Vietnam's membership in the World Trade Organization (WTO).

After the financial crisis and global economic downturn, it was necessary for Vietnam to restructure not only its economy but also the banking system comprehensively and synchronously as a key factor to ensure quick and sustainable development. In reality, the endeavor started in 2011 with the Government's adoption of the "Restructuring Financial Institutions 2011-2015" program (Decision no.254/QD-TTg dated March $1^{\text {st }}$ 2011). Although restructuring the banking system of Vietnam is not a new idea, (Note 1) it is a complicated, controversial and sensitive issue which has been debated for years yet progress has been slow and often too late. This paper examines the bank restructuring process from the viewpoint of international experiences and then, makes implications for current practices in Vietnam.

The banking system of Vietnam consists of the State Bank and credit institutions including 01 development bank, 01 bank for social policies, 05 commercial banks with state holding 100\% capital or dominating shares, 37 joint stock commercial banks, 54 branches of foreign banks, 05 banks with 100\% foreign capital, 05 joint-venture banks, 17 financial companies, 12 financial leasing companies, 01 Central People's Credit Fund, over 1,085 grass-root people's credit fund and 01 micro financial institution. Vietnam's credit institutions play a dominant role, accounting for $90.7 \%$ in credit market share and $88.92 \%$ in asset share of the whole system. The authors focus only on commercial banks. This restriction does not affect typical features of research subjects because the market share of credit and assets of commercial banks accounts for $86.47 \%$ and $84.44 \%$, respectively, of the whole system (Nguyen Thi Kim Thanh, 2012). Under the scope of research subjects, the research answers three main questions:

\section{i) What are international practices and experiences in bank restructure?}

ii) What are the main issues in the restructuring process of Vietnam commercial banks under the viewpoint of international practices? 
iii) What are the unknowns to be clarified during the restructuring process of Vietnam's banking system both from the viewpoint of international practices and reality?

The paper consists of five main sections: Introduction, reviews of international practices and experiences in bank restructure, research methodology, discussion ofthe unknown issues in Vietnam bank restructuring, and finally the conclusions.

\section{Literature Review}

There have been a number of international studies on restructuring and reforming of the banking system. Most studies have shown that the banking system restructuring is a major issue that has profound effects on the national economies. Restructuring includes four basic issues: 1) the concept and goals of restructuring, 2) the circumstances and conditions of the banking system before the restructuring; 3) the methods and implementation of restructuring, and 4) the evaluation of the effectiveness of restructuring (Dziobek, 1998; Goodhart, 1999; Hawkins, 1999; IMF, 1999). Highlight of these researches is the debate on the goals, context, and the selection of methods that are suitable to the restructuring in each economy.

\subsection{Purpose of bank restructuring}

Researchers have raised question: Is there a common goal and model for restructuring the banking system that can be applied to all countries?

According to the International Monetary Fund (IMF, 1999), restructuring the banking system is aimed to achieve three goals: (i) to strengthen the operational efficiency of the banking system through ensuring solvency and profitability, (ii) to improve the capacity of financial intermediation function of the banking system between the borrower and the lender, and (iii) to recover public confidence. Meanwhile, Waxman (1998) studied that the bank restructuring can be mentioned as a solution of a failed bank within the context of an effectively operating banking system. Restructuring individual banks is closely related to the restructuring of the whole banking system when they are particularly large in terms of scale. Two approaches have different scale but the same subject - the banking system in the deficient economies in developing countries which are integrated and transformed, where the banking system is dominated by a few large banks (also with less efficient operation). As it is proved that the collapse of one or more banks may affect over $20 \%$ of the total deposits of the banking system, banking system restructuring is a mechanism to deal with these banks to ensure the stability of the whole banking system. Thus, it is insufficient with IMF's goals. In poor countries, where people still lack of access to banking services, the government is required to maximize the mobilization of financial resources for poverty reduction, and large shocks in the banking system can lead to the collapse of the economy, the banking system restructuring may have other priorities. In other words, the objectives of restructuring the banking system depend on the context and practices of each country.

\subsection{Solutions for bank restructuring}

Implementation of bank restructuring requires a combination of solutions or measures. Studies on international experiences refer to the 6 following methods (Dziobek, 1998):

$\checkmark$ Government's capital injection or stock purchase to hold management rights

$\checkmark$ Closures of the banks which are unable to survive in an orderly manner (as well as paying deposit insurance or selling well-operated parts for other banks).

$\checkmark$ Merger of domestic banks with foreign banks.

$\checkmark \quad$ Merger of domestic banks.

$\checkmark$ Establishment of assets management company.

$\checkmark$ Change in bank ownership structure (e.g. privatization).

Dziobek (1998) suggested that in addition to the above measures, it is necessary to take macro-measures for each institution and legal factor to regulate and restore the problematic banking system in order to ensure sustainable solvency and profitability. For example, to change and reform regulations and policies on banking operations and to supervise the financial and banking system should also need undertaking. In fact, countries normally use a combination of methods (from 4 to 6 methods together), only a few countries use 2 methods such as Russia and Arabic countries (Demirguc-Kunt, Detragiache, and Poonam Gupta 2006).

Among these measures, changes in bank ownership and privatization bring the most significant changes in the banking system, followed by closures of banks, mergers of banks and government's purchase of stock. By contrast, when the central bank is assigned to be the only agency to restructure or support liquidity, the banking system 
changes slowly. This shows that not only the methods but also the organization of implementing restructuring and the implementation itself play very crucial roles.

In theory, merger and acquisition activities will help build shareholders' value through the creation of effectiveness or increase in market power. The general idea is that the value of the new bank after the merger and acquisition would be higher than the sum of the previous corresponding values of two independent banks. It should be noted that the merge with offshore banks is not as widely used as other measures because the openness to foreign investors depends on economic and political policies of each country (Quignon, 2006).

Regarding the method of closing banks that are not likely to survive in an orderly manner (as well as paying deposit insurance or selling well-operated parts for other banks), the advantage of this method is the fast removal of weak banks which cannot contribute to or negatively impact the economy if they exist. This method is suitable for small banks. According V.Sundararajan et al (1991), the Philippines successfully implemented this method to restructure in the 80s: 126 banks, 32 savings banks and 3 commercial banks were closed during $1981-1987$. When a bank is closed, deposit insurers may be responsible of payment and the bank will then be liquidated. The significant cost is the main drawback of this method, and the process of closing a bank causes a big lost on a number of services and banking jobs. Thus, Laurent Quignon (2006) proposed a mechanism handling weak banks based on a mechanism of classifying good and bad banks. Then the good bank is transferred to one or some banks having liquidity available to repurchase all or parts of the good bank. For bad banks, their shareholders themselves have to find resolution or eventually close their banks. In fact, this method has been successfully applied in many countries (though not fully applied or adjusted) in solving a number of failed banks in Canada, Japan, and South Korea.

Method of government's capital injection or stock purchase to hold management rights can cause greater impact to fiscal and monetary policies, increase government holdings of state banks and can lead to moral hazard.

The complexity of the banking system restructuring is also shown in that its operational implementation in different countries are various although the applications of restructuring methods are similar.

\subsection{International experiences in bank restructuring}

Studies on international experiences in implementing banking system restructuring showed that essential factor affecting the success of the restructuring is "speed" or the timeliness and agility. Hawkins and Turner (1999) compared the different responses of Japan and the Scandinavian countries to two serious crises in the past and concluded that the decisive actions and timeliness of the Scandinavian countries helped their banking system recover faster than that of Japan.

Planning to rectify banking system also plays an important part of the restructuring. The successful countries in bank restructuring tended to implement action plans in a year right after the weakness of the banking system was seen. Besides, all of them have properly assessed the situation, the nature and the severity of the weaknesses in the banking system. They also determined the causes and provided overall restructuring program. The Philippines is an example of having proper evaluation and banking system restructuring initiative. However, it should be noted that those successful countries have implemented the plan very flexibly and comprehensively.

Especially, it is very crucial to determine the agency which takes the main responsibility for implementing bank restructuring. In Thailand, the Financial Restructuring Advisory Committee was established to issue necessary instructions. Similarly, in Indonesia, the Indonesian Bank Restructuring Agency includes members of the state management bodies took the leading role. Thus, in terms of practice, central banks do not often directly play leadership roles and only involve as participants. John Hawkins (1999) conducted a survey on the restructuring of the 24 nations and showed that if the central banks were responsible for the restructuring, the banking system would change slowly and thus the banking system's restructuring would be difficult to work efficiently.

No matter what methods can be used is the combination of different methods very important factor, especially for a developing country.

According to Joseph Stiglitz (2002), restructuring the banking system would be much more difficult in developing countries by a number of basic reasons:

First, these countries often lack of regulations, science and institutional capacity for restructuring the system (e.g. handling mechanism of assets).

Second, in developing countries, the proportion of banks with liquidity shortages and bad assets accounts for a large proportion of the banking system, the number of banks operating effectively to be able for acquisition is less than the number of weak banks. 
Third, the banking system may be more complex, including state-owned and private banks. The state banks can operate with an implicit guarantee mechanism for depositors. The government's statement about not ensuring private banks can make withdrawals from those bank, especially if the government shut down a number of banks and cause doubts about the strengths of other banks in the system.

\subsection{International practices of evaluating the effectiveness of bank restructuring}

Dziobek (1998) used the indicators to measure the performance of three restructuring goals. For the first objective the operational efficiency, the author use both the sustainable solvency and profitability. Two financial ratios including delinquency ratio and the ratio of capital to total assets may be used to evaluate solvency whereas the three ratios include ratio of operating expenses to total assets, the ratio of interest income to total assets and ROA are used to assess the sustainable profitability of the bank.

To evaluate the performance of the capacity of financial intermediation function, the author used six criteria: credit growth of private sector/GDP growth rate, M2/GDP, changes in the interest rate differentials between input and output, the central bank loans/GDP, the real interest rate changes and the existence or the repetition of the problems in the banking system which have not been fully addressed.

By contrast, the efficiency of restoring public trust has not been ever evaluated and there has been no official documents referring to the measurement of public trust towards the banking system, even it is an important factor contributing to maintain the stability of the banking system.

\section{Methodology}

For the above objectives, the authors used both qualitative and quantitative research methodologies to analyze secondary as well as primary data.

\subsection{Secondary Data}

For the research, the authors used secondary data from the financial statements of 44 commercial banks(excluding foreign banks), research and reports on finance and banking of the State Bank of Vietnam, World Bank (WB), International Monetary Fund (IMF), Asian Development Bank (ADB) and other domestic and international financial institutions.

\subsection{Primary Data}

The authors surveyed 44 commercial banks and conducted in-depth interviews with 20 experts and policy-makers in finance and banking from February to March 2012 in order to collect ideas, opinions and information for qualitative analysis.

The survey sample include almost commercial banks in Vietnam: 44 banks (including 5 State commercial banks; 11 joint stock commercial banks with total assets of over 80 trillion VND; 25 joint stock commercial banks with total assets below 80 trillion VND and 3 foreign banks). The authors conducted in-depth interviews with 20 experts (including 7 research experts; 3 policy-makers; 02 senior managers of State commercial banks and 8 senior managers of joint stock commercial banks).

Table 1. A summary of surveyed banks and in-depth interviews

\begin{tabular}{clc}
\hline No & \multicolumn{1}{c}{ Name of banks } & Number of surveyed banks \\
\hline 1 & State - owned commercial banks & 5 \\
2 & $\begin{array}{l}\text { Group of joint stock commercial banks with total assets of } \\
\text { over 80 000 billion }\end{array}$ & 11 \\
3 & Group of foreign banks & 3 \\
4 & $\begin{array}{l}\text { Group of joint-stock commercial banks with total assets of } \\
\text { under 80 trillion }\end{array}$ & 25 \\
& Total & $\mathbf{4 4}$ \\
\hline
\end{tabular}

\begin{tabular}{lllllr}
\hline \multicolumn{7}{c}{ A summary of in-depth interviews } \\
\hline & Professionals, & Policy & CEO of state-owned & CEO of joint stock & Total \\
Subject & researchers & makers & commercial banks & commercial banks & \\
Number & 7 & 3 & & 2 & $\mathbf{2 0}$ \\
\hline
\end{tabular}




\subsection{Questionaire}

To examine the differences or appropriateness of Vietnam banking restructure with the internatioanl practices, the semi-structure questions are designed to receive the assessment of the interviewees.

The likekert scale is used to assess the efficiency of measures conducted by Vietnamese Government in the bank restructure as well as the impact of difficullties and obstacles.

\section{Results and Discussion}

This section reviews the program on restructuring banks in Vietnam in the following aspects: restructuring subjects, restructuring model and authority in charge of the bank restructuring, solutions to restructuring, and restructuring plan. Using the survey results, the paper identifies the gaps and the unknowns for the success of restructuring of Vietnam commercial banks.

\subsection{Objectives for restructuring}

There are two common approaches to the bank restructuring in line with international practices, of which are IMF (1999) and Waxman (1998).

Survey results show that more than $38 \%$ respondents thought that banking restructuring in Vietnam means restructuring the entire banking system, including the State bank of Vietnam, commercial banks, and non-banking credit institutions. By comparison, about $30 \%$ of respondents thought that bank restructuring should focus on commercial banks and credit institutions, and only about $20 \%$ thought that restructuring should only focus on commercial banks. There is a common view that the management of monetary policies of the State Bank had been unable to anticipate changes, and thus pushing commercial banks into a passive state. Therefore, it can be seen that an important subject that has major influences on the operation of commercial banks and credit institutions is the State Bank. In order to restructure the banking system comprehensively, the restructuring/reform of the State bank should be considered in the long-term; restructuring of only commercial banks is not adequate. In addition, such banks as Bank for Social Policies and Vietnam Development Bank also need restructuring in line with new context.

\subsection{Solutions to bank restructuring}

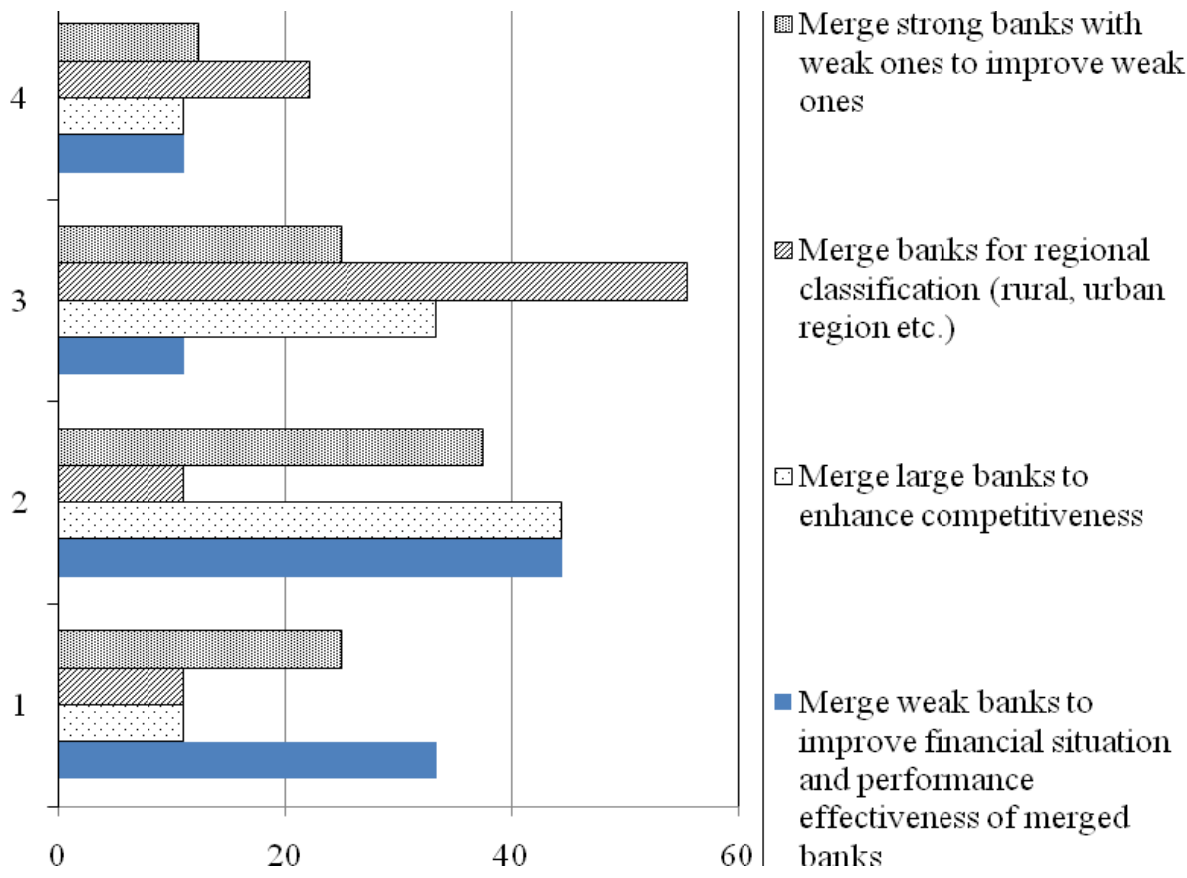

Figure 1. Efficiency of banks' merger if implemented in Vietnam

*The effectiveness is valued from 1 - The lowest to 4 - The highest.

There are two methods implemented in Vietnam now, namely merging domestic banks with one another and encouraging foreign banks to hold shares in domestic banks to expand room for foreign investors in financial and banking sectors. This demonstrates that the approach of Vietnam in restructuring is relatively appropriate in comparison with international practices. However, there are different opinions on the effectiveness of these two solutions. Figure 1 indicated that the most efficient method, at level 4, is merging strong banks with weak ones to improve weak ones. However, only $10 \%$ respondents appreciated this method because they thought that merging strong banks with weak ones would invite certain costs, and could actually weaken strong banks. The most favored 
method at present is merging banks for classification of bank under business sector (accounting for over 55\% at level 3). $45 \%$ respondents think that it would be inefficient to merge weak banks and merge large banks to improve competitiveness.

Vietnam's banks have low capital ratio (See Figure 2). In line with international practices, there are 4 solutions commonly used to increase capital for banks. According to survey results, over $40 \%$ respondents consider increasing room for foreign investors the most effective measure. More than 55\% respondents consider contribution of the government's reciprocal capital besides private capital relatively efficient. However, according to Laurent Quignon (2006), this solution can have negative influences on fiscal and monetary policies. In addition, increasing the equity of the state in banks can lead to moral hazards.

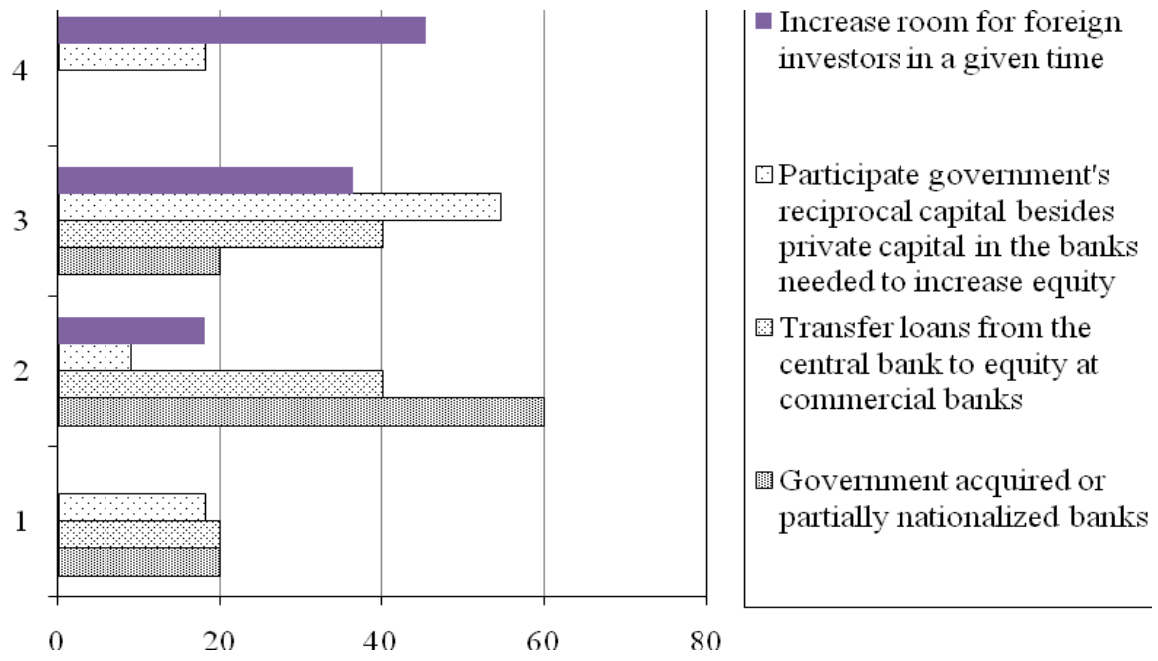

Figure 2. The effectiveness of some solutions to raise capital ratio (if implemented in Vietnam)

*The effectiveness is valued from 1 - The lowest to 4 - The highest.

In Figure 3, over $60 \%$ respondents considered lending of the State Bank on the basis of guaranteed bond issued by commercial banks a relatively effective way to improve liquidity of banks (level 3). The solution, however, has not been implemented strongly in Vietnam now. At the same time, whereas over 55\% respondents saw capital injection of the State Bank to banks having difficulties in liquidity as ineffective (at level 2), this solution has actually been applied commonly. Moreover, the solution that requires big banks (e.g. BIDV and VCB) to support and cooperate with small banks to handle difficulties in liquidity is also considered the most effective; however, the solution seems effective only when the crisis is not matured and liquidity pressure due to interest competitiveness is not really strong.
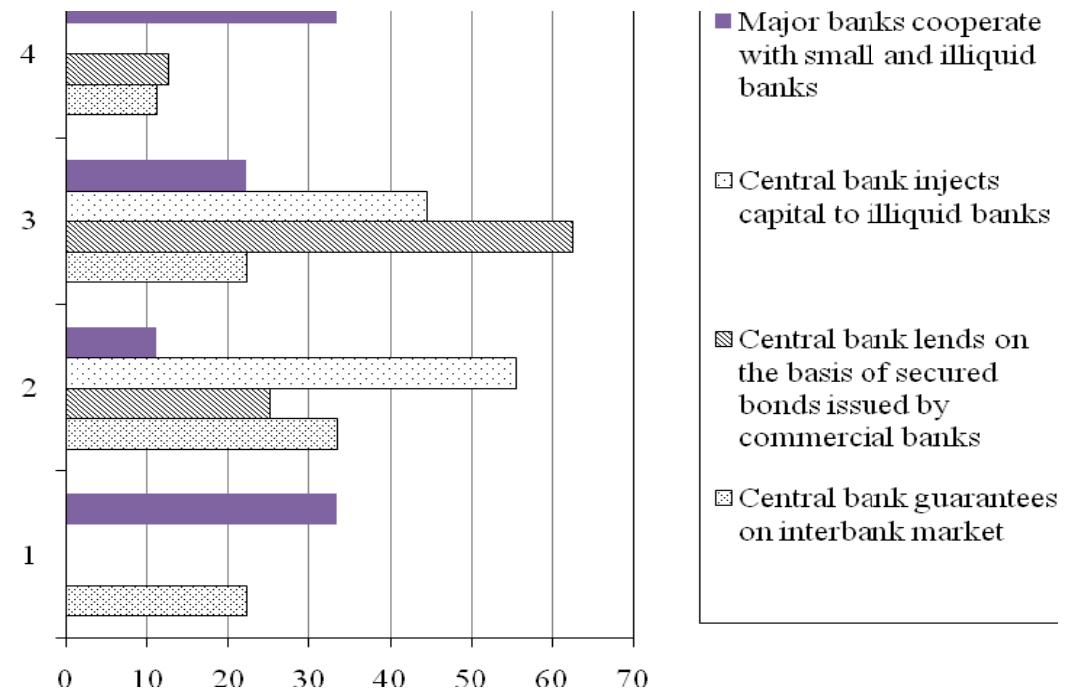

Figure 3. The effectiveness of some solutions to improve commercial banks' liquidity position in the bank restructuring procedure

*The effectiveness is valued from 1 - The lowest to 4 - The highest. 
In line with international practices, closing banks without survival ability (together with simultaneous payment of deposit insurance or selling of their healthy parts to other banks) is one of the most prioritized solutions to handling weak banks (Dziobek, 1998). Based on survey results shown in Figure 4, forced closure of weak banks are supported the most (60\%) with a fairly high level of effectiveness (at level 3). Do Thien Anh Tuan (2012) said that bank owners, who directly sign contracts of deposits with clients, and not the Government, must take responsibility for the escalation from the anxiety of depositors due to unguaranteed rights to the collapse of the system. If the Government commits not to let banks collapse, they protect the bankers. Thus, the message that banks are not let collapse implies that shareholders' interests are protected instead of depositors'. The bankruptcy of weak banks, on the other hand, is a meaningful punishment with much smaller costs than any other commitment of the Government.

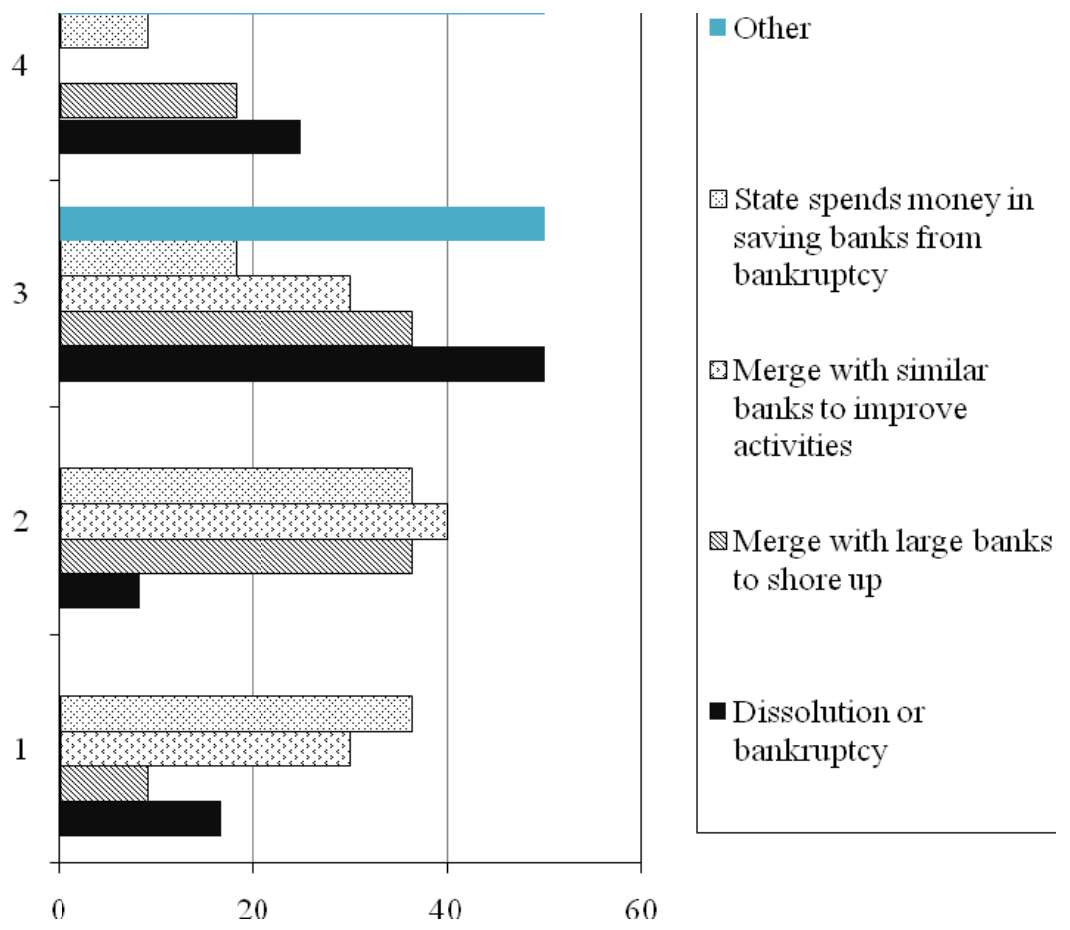

Figure 4. The effectiveness of some solutions to weak, illiquid, unprofitable banks (if implemented)

*The effectiveness is valued from 1 - The lowest to 4 - The highest.

The effectiveness of merging weak banks with better banks or other weak banks is perceived as low (at level 2) by over $40 \%$ respondents. $30 \%$ respondents also thought that spending state money in saving banks from bankruptcy is not an effective solution. However, it can be used when other solutions seems ineffective, or for socio-political purposes. Respondents also accept that it is possible to sell weak banks to foreign investors or partners. However, foreign investors are only interested in buying the majority of shares of small banks in order to bring about changes on their own. Since the cap of foreign equity is at $30 \%$, however, this demand is practically impossible: the investment capital is too small for them to be actively involved in banks' decision-making.

Improving public's trust in the banking system is one of 3 purposes of the bank restructuring set out by the IMF (IMF, 1999). Nearly $60 \%$ respondents see that enhancing the information transparency of the banking system is an effective solution (See Figure 5). Over 60\% respondents consider increasing the compliance of regulations in the banking system fairly effective. In spite of being supported by nearly $50 \%$ respondents, the effectiveness of improving the efficiency of inspection and supervision is considered very low. Increasing deposit insurance fees is not supported and has low effectiveness. Experts also thought that, in the current context, depositors must wisely select prestigious banks to deposit, rather than follow the interest rate races. Then, information publicity and transparency in the banking system plays an important role. If the insurance fee increases, in case of risks, depositors will be the first losers, except that they receive $100 \%$ insurance. Moreover, the deposit insurance fee should be calculated on the basis of risks of banks instead of a uniform level of $0.15 \%$ deposits, as well as according to the percentage of deposits instead of a 50 million VND flat-rate as it currently is. 


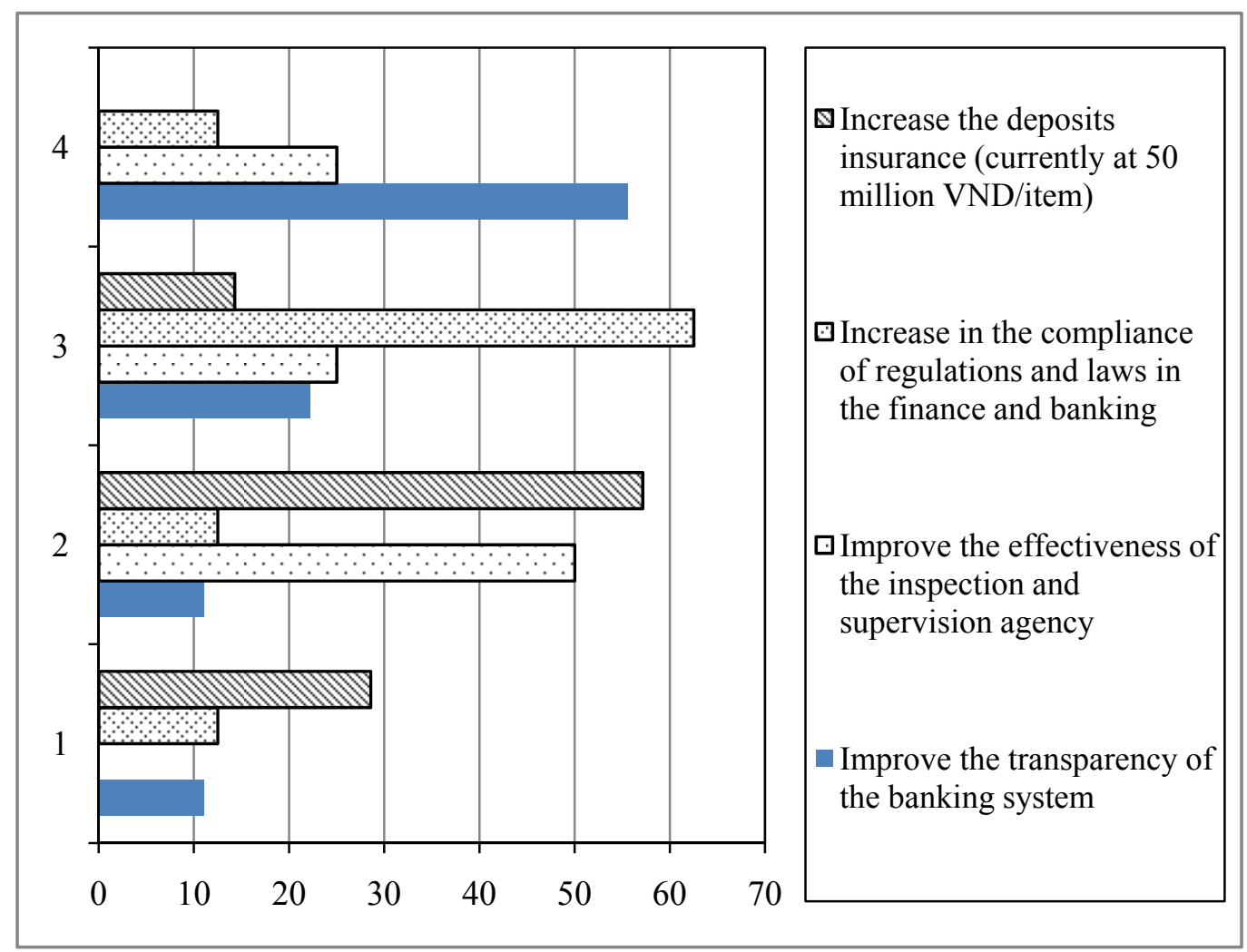

Figure 5. The effectiveness of solutions to improve the public's trust in the banking system

*The effectiveness is valued from 1 - The lowest to 4 - The highest

\subsection{Restructuring roadmap}

\subsubsection{In the Short-term:}

According to survey results, accurate determination and handling of bad debts are prioritized first as short-term solutions to restructure the banking system currently (with $35 \%$ respondents), subsequently, there are increasing equity capital and increasing the public's confidence in the bank system (accounting for $26 \%$ and $22 \%$ respectively). Classifying banks to control the credit growth is only agreed by $13 \%$ respondents. One of the biggest concern of experts and leaders of banks is how to accurately determine and handle the non-performing loan ratio in order to properly evaluate on-going situation and give solutions.

Some experts think that regulation on the minimum equity capital will put small banks in increasing pressure, because at that time their management capability has not been improved to match the twenty-fold increase in scale of total assets (as bank increases its equity capital from 2 trillion VND to 3 trillion VND, it is possible to raise total assets to 20 trillion VND). Do Thien Anh Tuan (2012) contends that this forced banks, especially joint stock rural banks and small-scale banks, to compete with each other in order to increase their equity capital urgently while the management capability has not matched its scale. Still the old managers and managing apparatus, they now have to run a much bigger bank in a more competitive environment. As a result, when the economy is unstable, weaknesses gradually come out, leading to the need for this very restructuring project. Thus, instead of stipulating the minimum equity capital, the government agency for Banking Supervision should set out regulation on CAR index and specific supervision mechanism to ensure sound operation of banks and facilitate banks to actively increase or reduce their scale proper to their governance.

Most of the solutions have been suggested in the program; however, measures to improve the public trust remain unspecified. What would be the methodology to measure the public's trust? How can the public trust indicator be improved? And even when public trust can be measured and identified, it still would not be easy for the State Bank to improve it in the short-term.

\subsubsection{In the Long-term}

According to survey results, among long-term solutions, the first priority is given to improvement of supervision 
function of the State Bank and corporate governance of commercial banks (with $50 \%$ respondents). This is completely proper to analysis and assessment on weaknesses of commercial banks.

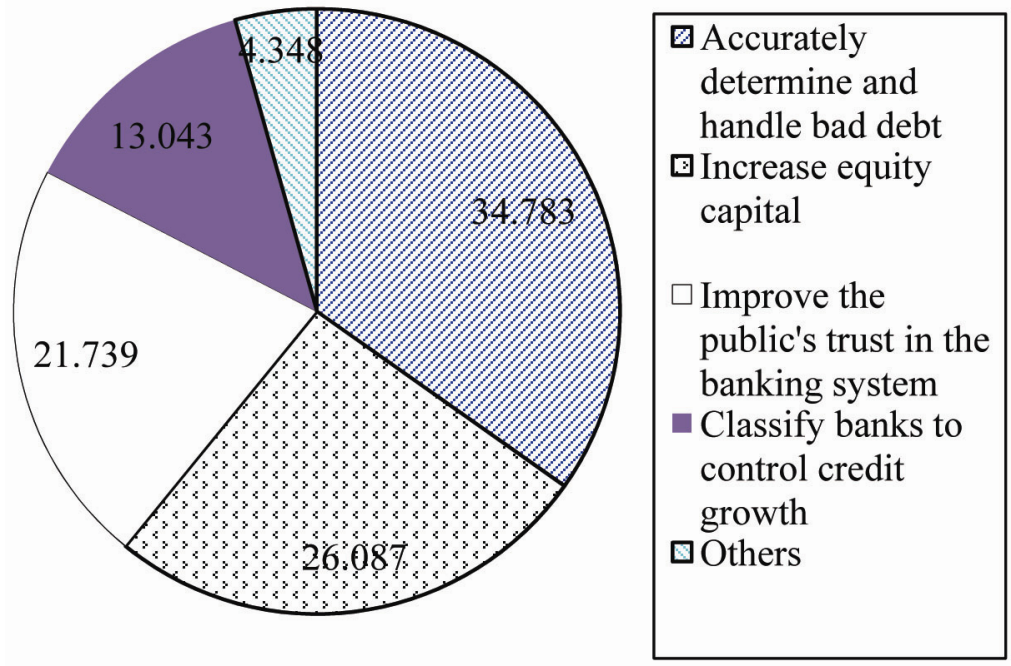

Figure 6. Restructuring Solutions in the short-term

However, the improvement of the supervision function of the State Bank is related to its restructuring, which is not mentioned specifically in the program. In addition, some experts think it is necessary to improve the management of monetary policies of the State Bank (with $6 \%$ respondents). This is not surprising since several experts believe that a liquidity shortage of many commercial banks is caused by not only their own problem but also by the responsive and temporary policies of the State Bank.

Corporate governance of commercial banks is one of the important causes of U.S. Banks' collapse in the crisis period of 2007-2008. The paper has pointed out the existence of a discrepancy between governance of Vietnam commercial banks and international practices in OECD corporate governance. Although there were no grounds to conclude the relationship between corporate governance and profitability of commercial banks at the time of research, the paper has also identified a discrepancy between CGI of listed commercial banks and non-listed ones. Hence, the improvement of corporate governance will contribute to improving information transparency in operation of commercial banks in the long-term.

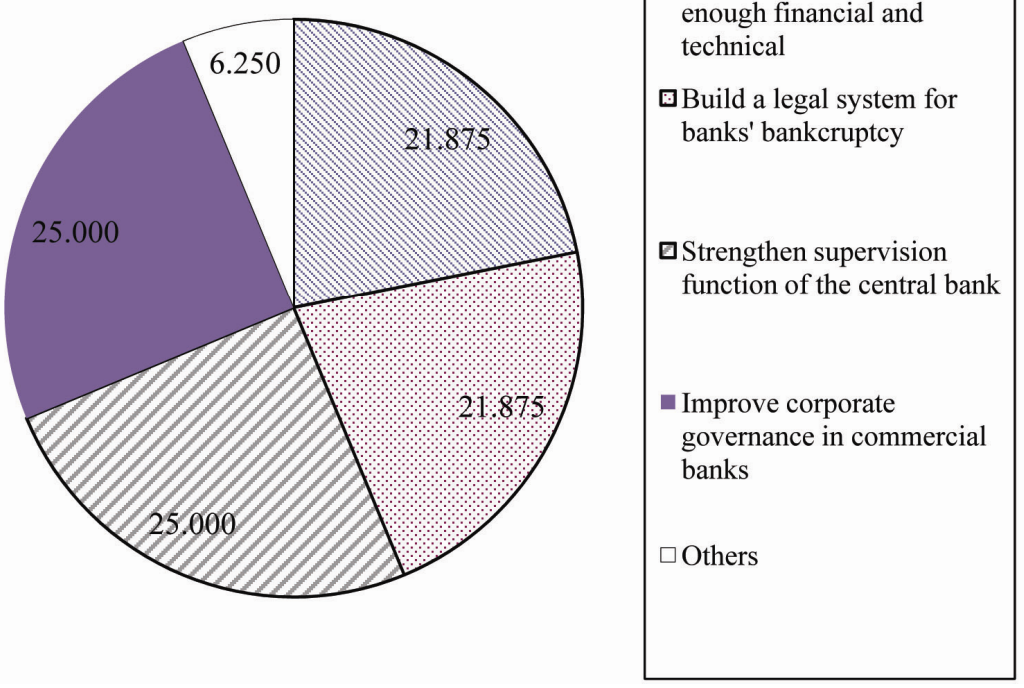

Figure 7. Restructuring Solutions in the Long-term

There are $22 \%$ respondents believed that in the long-term, it is necessary to (i) build a legal system so that deposit insurance has enough financial and technical capacity to handle banks' breakdown and (ii) build a legal system for banks' bankruptcy. The two solutions have a close relationship because only when the laws allow banks' bankruptcy 
and when deposit insurance is strong enough, banks' bankruptcy and handling of banks' bankruptcy will follow the market force. These two solutions are also perfectly in line with international practices; however, they have yet to be mentioned in the current Program.

In addition, in the long-term, it is necessary to establish the national financial safety net. According to Fred Carns (2011) and Hiroyuki Obata (2011), a financial safety net is a system of agencies in charge of supervising, maintaining the stability of the financial system, and preventing crises in countries. This is together with the mechanisms and instruments applied by these agencies in order to accomplish their objective. In compliance with international practices, the financial safety net of countries typically consists of the Ministry of Finance, the Central Bank, the Agency for Financial Supervision, the Deposit Insurance Agency and other authorities. Within this financial safety net, deposit insurance has the functions of maintaining depositors' trust with a role of supervising, early warning and handling banks' breakdown. Overall, it ensures the safety of the system by contributing to the prevention and positive handling of crises. Thus, deposit insurance agencies play an important role in protecting depositors and stabilizing the financial system. It can be seen that with current global trends the roles of deposit insurance agencies have been strengthened by applying higher limits, enhancing capital resources, deposit insurance funds, quick payment and transparent handling mechanisms under the participation of deposit insurance agencies.

\subsubsection{Authority in Charge of Restructuring}

The authority in charge of restructuring is also important to the success of restructuring. In Thailand, the Corporate Debt Restructuring Advisory Committee is established to issue essential instructions. The Committee is led by the Deputy Minister of Finance and consists of members as the Central Bank, Ministry of Finance and the private sector. Similarly, in Indonesia, the Agency for Indonesia Bank Restructuring, which consists of members of state management authorities, is in charge of restructuring. Thus, in reality, the central bank does not give direct instruction but only participates in restructuring. John Hawkins (1999) who researched on bank restructuring in 24 countries recognized that if the state bank takes charge, the banking system will slowly change and thus it is difficult to have a highly effective restructuring process.

The survey shows that the authority taking the major charge of implementing the restructuring should be the State Bank of Vietnam (77\%); or The Ministry of Finance (11\%); other ideas suggested to form a Restructuring Committee belonging to the Government similar to experience of Japan or Korea. Experts also identify several advantages when the State Bank takes charge of restructuring: for example, because the State Bank directly manages the banking system, it can access information easily to master the practical situation of the system (classifying banks for credit growth control), apply administrative measures easily in fostering restructuring solutions (encouraging big banks to support/buy small ones). Many ideas, however, also indicate limits of the model such as (i) lack of transparent information, given that only the SBV knows the restructuring plan before publishing (ii) lack of co-operation of related-parties as the MOF, National Financial Supervisory Commission (iii) potentially inaccurate identification of the cost for restructuring, and (iv) possible conflict in interest or issues on group' interest.

\subsubsection{Major Difficulties and Challenges}

According to Joseph Stiglitz, World Bank chief economist, it is much more difficult to restructure the system because of several key reasons: i) lack of legal, scientific and institutional grounds for restructuring (for example, mechanism on asset handling); ii) Illiquid banks with bad assets account for a large percentage in the banking system while efficient banks which can buy and control weak ones are much fewer in number; iii) the banking system can be more complicated, including state banks and private banks. State banks can operate with an implicit depositor guarantee mechanism. The government's declarations to not providing guarantee for private banks can result in deposits withdrawal from these banks, especially if the government closes some banks and cause doubts on the healthiness of other banks in the system.

According to survey results, the two biggest difficulties hindering the bank restructuring in Vietnam are (i) lack of the public trust and (ii) lack of legal grounds for restructuring, agreed by over $50 \%$ of respondents, while subsequently (iii) Inaccurate determination of bad debts and (iv) Government's financial difficulties with regards to restructuring are agreed by nearly $40 \%$ respondents. This can explain why the program on the bank restructuring insists on no-bank-breakdown and cannot be specific when determining of costs for restructuring.

Some experts also believe that the decisiveness, timeliness and toughness of actions and measures on restructuring are also crucial factors of success. Moreover, according to Dziobek (1998), in terms of assessment on restructuring efficiency in Asia, the Philippines obtained considerable changes after its restructuring, which started from 1984 at the cost of $4 \%$ GDP. This is the country that implemented restructuring actively. On the other hand, Korea started 
restructuring in 1993 and achieved moderate changes in the banking system. Japan gained slow changes; indecisive measures at narrow scale are one of factors that caused time delay in the country bank restructuring.

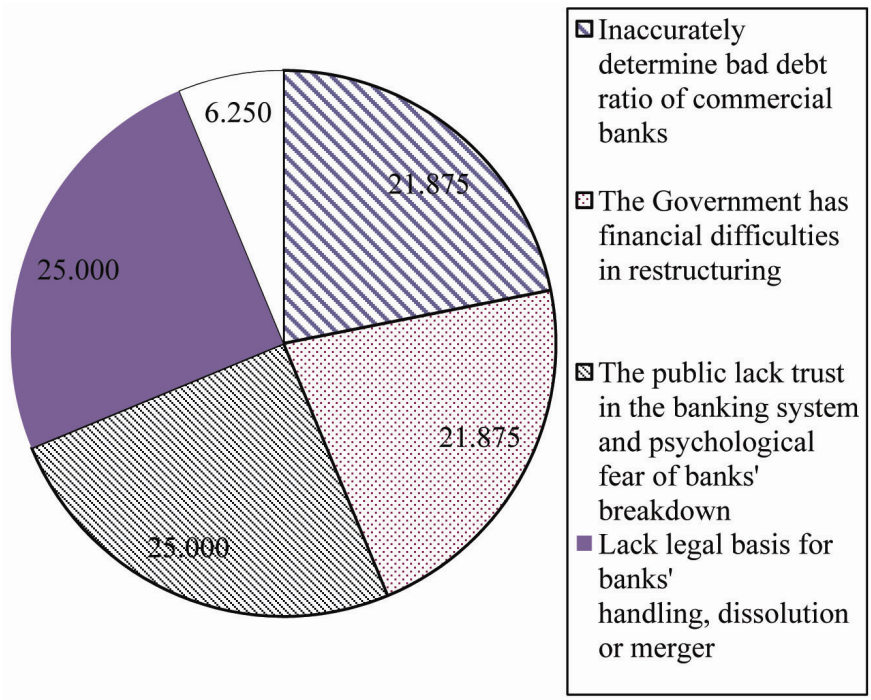

Figure 8. Major difficulties and challenges in restructuring the banking system in Vietnam 4.3.5 Other Factors that Influence the Restructuring Process

According to Vo Tri Thanh (2012), operational risks are also related to cross-ownership of equity capital among commercial banks, corporations/groups having finance and real estate-related activities. This situation creates interest groups which can govern the market, making it difficult to clearly separate the ownership, thus hindering banking supervision and restructuring. $40 \%$ respondents thought that the cross-ownership between banks and enterprises had significant influence (3.4/4). In addition, nearly $40 \%$ of respondents thought that other factors such as political benefits and group benefits had the strongest influences on restructuring. According to experts, the uncontrollable cross-ownership among banks as well as between banks and enterprises causes conflicts of interests between groups. According to Do Thien Anh Tuan (2012), although these forms of ownership are said to be diverse, including state ownership, collective ownership, foreign ownership and private ownership, they are not the same in reality. Evidently, the government only sells a small part of shares of commercial banks to the public, which has no effect upon the ownership characteristic of these banks. Similarly, joint stock banks generally are small scale with limited public shareholders; in reality, their ownership characteristics are much more similar to cross-ownership and family ownership. The lack of transparency in ownership is the root of moral hazards, weaknesses and threats. Therefore, ownership diversification in principle alone is not as important as improving transparency of ownership.

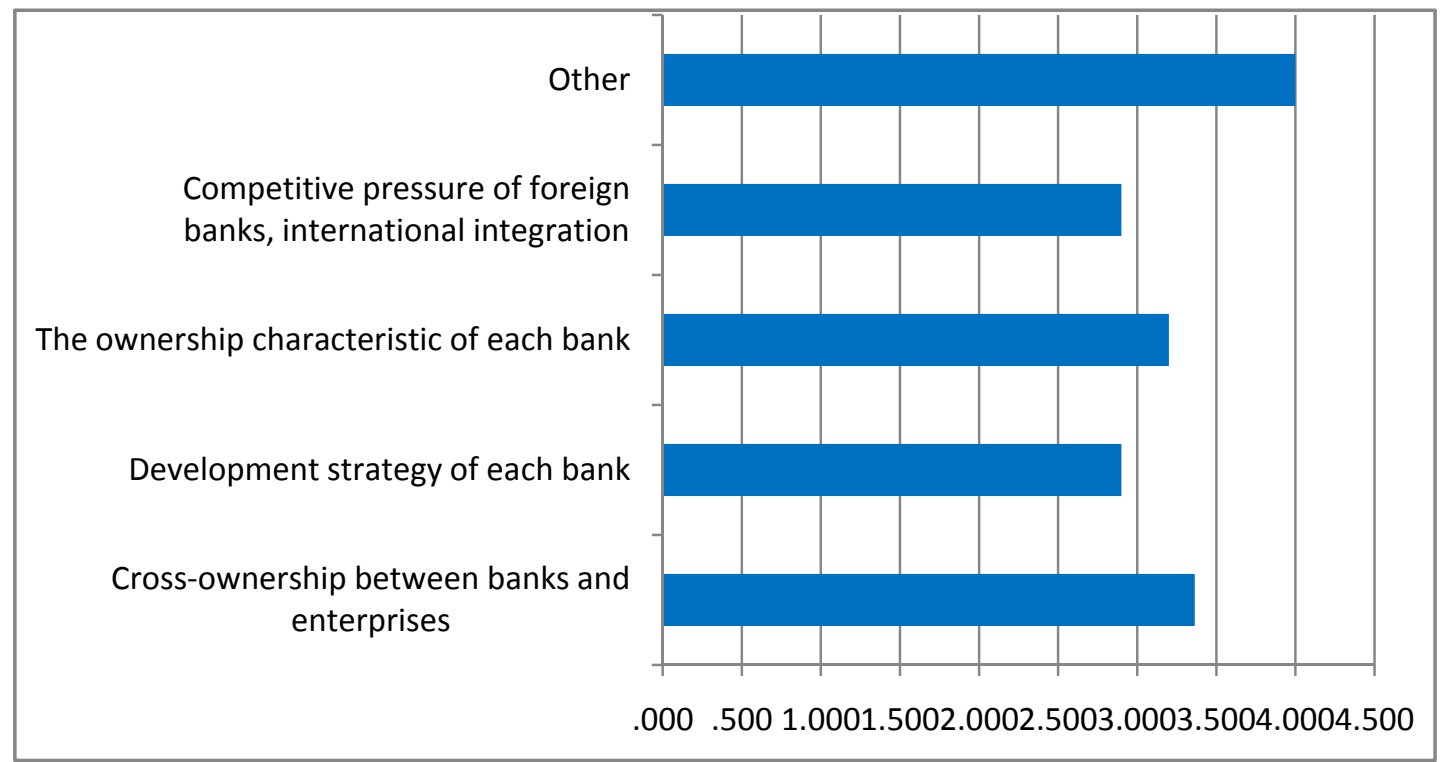

Figure 9. Factors that influence the restructuring process of the banking system in Vietnam 


\subsubsection{Cross-Ownership in the Banking System of Vietnam}

Legal framework: The 2010 Credit Law stipulates that commercial banks can only use their charter capital and capital provisions to contribute equity capital or buy shares in other enterprises. Moreover, capital pooling and share purchase of commercial banks shall observe several stipulated limits: currently, banks can't own more than 11\% charter capital of other enterprises or credit institutions. Hence, in terms of policies, the State Bank of Vietnam does not ban cross-ownership, but merely restricts it through regulations on ownership ratio.

Vietnamese banking system in practices: The cross-ownership network in Vietnam is very substantial and little information is disclosed. The cross-investment can be publicized or not. The information can be disclosed in financial statements or prospectuses of banks, but not all banks choose to disclose information on the mass media; and even if they do, the information is often insufficient and out-of-date. Notably, there were three milestone changes in the banking system that actually forced banks to cooperate with each other via cross-ownership. In 2006, the minimum charter capital was increased to 1 trillion VND; in 2008, it rose to 3 trillion VND; and in 2011, the restructuring process started by merging three joint stock commercial banks. Because of this process, a group of banks or individuals will become owners of various banks simultaneously.

In Vietnam, cross-ownership takes the form where enterprises own banks or banks own enterprises. A great number of enterprises pool capital and become big shareholders of banks. Along with main ownership there is lending-borrowing relationship. Banks refund enterprises with very large loans. Similarly, banks pool capital or establish a lot of subsidiary companies (See Appendix 3) and can lend the companies. Banks can lend other quality projects and groups. However, due to the close relationships in cross ownership, banks still lend even unprofitable enterprises. In sum, this is a form of money squeezing. In the banking system, increases in system risks lead to increases in credit risks. In the entire economy, transferring capital to the economy through the banking system will be inefficient if the "network" of cross-ownership is too large and uncontrollable.

Information transparency: It is not easy to find information on credit institutions which buy shares from others. Not all banks publicize their investment ratios in other credit institutions. Cases of official publicity such as Vietcombank and Vietinbank seem rare. Moreover, practical cross-ownership among banks is probably not fully reflected by these figures. Therefore, the greater threat becomes that resources of the banking system - the blood vessel of the economy - are not substantive because of non-transparency.

\subsection{Unknowns in the Restructuring Process of Vietnam Banking System}

\subsubsection{Model of Banking System after Restructuring}

The program has not specified indicators on quantity, scale and types of banks. The program draws up a "bright" picture of a healthier, more competitive and more efficient banking system. However, the banking model after restructuring has not been defined: Are investment banks formed? Are banks to develop in a multi or uni-functional orientation? Pending the State regulations, commercial banks can still act as investment banks by investing heavily on securities and real estate, and their investment risks can translate to banking risks.

\subsubsection{Financial Source}

The program has not identified the cost and the resources for the entire restructuring process, including estimates losses and required financial resources for restructuring. Even when the big banks provide financial support to weak ones, there remains a burden of financial losses for these big banks. So far, the Ministry of Finance has not identified the sources of funding for the restructuring package. In line with international practices, financial resources for cleaning up/handling weak banks are often defined, including: resources of bank acquisition, including acquisitions that comes as the results of increasing room for foreign investors; resources from liquidated assets of handled banks; resources from bank owners; resources from the issuance of the government's bonds through deposit insurance; etc. The government may not have to spend money on handling banks (even getting benefits) when it nationalizes weak banks (Korea), recover them, and then sell them to the private sector. However, in case the government spends money on supporting weak banks, like the experience of Korea, it will need to issue regulations to ensure efficiency of the restructuring as well as minimize moral hazard. Banks are required to cut down scale, staff, branches, improvement of productivity and efficiency if to receive supports from the government in the restructuring process. In case of unprofitability and weak management, banks have to reduce capital and replace leaders.

\subsubsection{Roles of Debt and Asset Trading Corporation (DATC)}

In accordance with international practices, an efficient debt market will be a channel to transform low quality assets and loans of weak banks the most quickly and effectively. In the market, the AMC will be a focal point for trading 
the assets and outstanding loans of banks and enterprises. According to the experience of Korea, Korean Asset Management Corporation (KAMCO) bought 32,500 billion WON of NPLs by direct payment in the form of issuing bonds of KAMCO to banks. KAMCO will buy non-performing loans at price of $45 \%$ mortgaged book value and $3 \%$ unmortgaged book value. Clearly, in order to perform its role in the debt trading market, DATC shall have sufficient financial resources, or be allowed to issue bonds guaranteed by the government, and apply a debt trading mechanism based on the quality of non-performing loans.

\subsubsection{Coordination among Related Parties in the Process of Banking System Restructuring}

The model where the State Bank takes charge of restructuring is also popular in some countries in the world. However, in Vietnam, a national agency/committee for restructuring should be founded, including the State Bank as a coordinator and other relevant parties such as the Ministry of Finance, Deposit Insurance, AMC and National Agency for Financial Supervision. Then, difficulties and shortcomings related to financial resources for restructuring, supervision mechanism in the restructuring process, treatment and protection of depositors' interests, handling of guaranteed assets and bad debts, especially relationship between restructuring of the banking system and state-owned enterprises, public investment restructuring and restructuring of the securities market in the context of restructuring the entire economy can be handled. Vo Tri Thanh (2012), has also provided some answers to unaddressed issues in the program: (i) restructure the financial system together with stabilizing the credit market and improving the role of the stock market in mobilizing long-term capital for enterprises, (ii) reform the financial market supervision model and method, (iii) widely apply international standards and ensure honesty, validity and sanctions in applying standards of accounting, international auditing, international financial statements and the system of statistics and evaluation of corporate assets, and (iv) restructure the structure of credit and banking markets

4.4.5 Connection between Banking System Restructuring and Public Investment Restructuring and State Owned Enterprise Restructuring

Because nearly $40 \%$ of outstanding loans in the banking sector are lent to state-owned enterprises, the debt to equity ratio of state-owned economic corporations is $27.6 \%$ (by 12/2011), meanwhile, this ratio is $27.2 \%$ in Korea and $7.62 \%$ in China (Vu Thanh Tu Anh, 2012). Do Thien Anh Tuan (2012) remarks that, due to the fast development of the economy without consideration for the impacts of bank restructuring, state-owned-Enterprise restructuring and public investment restructuring on the formation of the new economic conditions, the form of credit institutions should be made compatible for the new economy but not the current one.

\subsubsection{Methods to Assess the Effectiveness of the Restructuring Process}

In the context of restructuring the banking system in Vietnam, in addition to two indicators on assessment of efficiency and improvement of the role of financial intermediaries, the authors suggest supplementing: (i) competitiveness, (ii) access to SMEs and rural areas and the poor, (iii) risk management and corporate governance, (iv) total costs and cost allocation among three agents related to the bank restructuring i.e. bank owners, government and people.

\section{Limitations and Suggestions for Future Research}

One of the major difficulties when conducting the research is the problem of information transparency. It is not easy to find information on credit institutions which buy shares from others. This is because not all banks publicize their investment ratios in other credit institutions, and cases of official publicity like Vietcombank and Vietinbank seem rare. Moreover, practical cross-ownership among banks is probably not fully reflected by these figures. This problem sometimes leads to insufficient and imprecise data for proper analysis.

While analyzing Vietnam practices from perspectives of international theories and practices, the research have not considered all the major differences of Vietnam banking system and that of other countries, which is partly because of the lack of information. Therefore, future research may be conducted in depth to give more precise perspectives of Vietnam bank restructuring and to bring useful guides for Vietnam practices.

\section{Conclusions}

From 2010 to the first quarter of 2012, in addition to directly-related factors such as high inflation, frozen real estate and stock markets and a stagnation of enterprises, the activities of commercial banking system were considerably affected by the direct solutions and policies of the State Bank of Vietnam.

The restructuring of commercial banks started on the basis of the policy "Restructuring financial institutions in 2011-2015." It can be seen that Vietnam has an active approach in restructuring its banking system in order to obtain targets the most effectively in the circumstance of no risks of severe crisis or regression. In the viewpoint of theory 
and reality, however, there remain a lot of issues related to subjects, measures, procedure, difficulties, challenges and other influential factors to be researched, supplemented and specified.

In order to succeed in restructuring the banking system of Vietnam, international theories and practices and the practical context of Vietnam show that it is necessary to clarify several unknowns related to the model/format of the banking system after restructuring, the financial resources for restructuring, the roles of Debt and Asset Trading Corporation in the restructuring procedure, the cooperation between leading agencies and cooperative authorities in the restructuring procedure, the connection of banking system restructuring, the restructuring of public investment and state-owned enterprise, and the approaches/methods of assessing the efficiency of restructuring.

\section{References}

Augustin Landier \& Kenichi Ueda. (2009). "The Economics of Bank Restructuring: Understanding the Options".

Barth, J.R; Dopico, L.G; Nolle, D.E; Wilcox, J.A. (2002). "Bank Safety and Soundness and the Structure of Bank Supervision: A Cross-Country Analysis", International Review of Finance, 3( 3-4), pp. 163-188. http://dx.doi.org/10.1111/j.1369-412X.2002.00037.x

Barth J.R.; Nolle D.E.; Phumiwasana T.; Yago G. (2003). "A Cross-Country Analysis of the Bank Supervisory Framework and Bank Performance", Financial Markets, Institutions \& Instruments, 12(2), pp. 67-120. http://dx.doi.org/10.1111/1468-0416.t01-2-00001

Ben S.Bernanke. (2009). Lessons of the financial crisis for banking supervision.

Claudia Dziobeck \& CeylaPazarbasioglu. (1998). "Lessons from Systemic Bank Restructuring”, IMF.

DoThien Anh Tuan. (2012). "Some issues of the Program of Banking Restructure", Sài Gòn Economics Times, $15 / 4 / 2012$.

Dominique Strauss-Kahn. (2009). "Need to fix banking sector for stimulus to work", IMF.

Donato M., Marc Q., Michael W. Taylor. (2008). "Inside and outside the central bank: Independence and accountability in financial supervision: Trends and determinants", European Journal of Political Economy, 24(4), pp. 833-848. http://dx.doi.org/10.1016/j.ejpoleco.2008.07.005

Dookyung Kim. (1999). "Bank restructuring in Korea", BIS policy paper No. 6. pages 143 - 151.

Friedman, B M. (1999). "The Future of Monetary Policy: The Central Bank as an Army with Only a Signal Corps?" International Finance, 2(3), pp. 321-338. http://dx.doi.org/10.1111/1468-2362.00032

Friedman, B M. (2000). "Decoupling at the Margin: The Threat to Monetary Policy from the Electronic Revolution in Banking", International Finance, 3(2), pp. 261. http://dx.doi.org/10.1111/1468-2362.00051

$\mathrm{Fu}, \mathrm{X} \&$ Herffernan, S.A. (2009). “ The effects reform on China's Bank Structure and Performance”, Journal of Banking and Finance. http://dx.doi.org/10.1016/j.jbankfin.2006.11.023

Goodhart C.A.E. (2002). "The Organizational Structure of Banking Supervision”, Economic Notes, 31(1), pp. 1-32. http://dx.doi.org/10.1111/1468-0300.00070

Goodhart et al. (1998). "Financial regulation: Why, how and where now?", Bank of England.

Goldstein, M và P. Turner. (1996). "Banking crises in emerging economies: origins and policy options", BIS economic papers, No. 46 October.

Hawkins, J. (2001). "Electronic finance and monetary policy Workshop on Electronic Finance: a new perspective and challenges", The Bank for International Settlements.

IMF (1998). "Financial Crisis: Characteristics and indicators of vulnerability".

IMF. (2006). "A compilation guide to financial soundness indicators".

Ioannidou, V.P. (2005). "Does monetary policy affect the central bank's role in bank supervision?" Journal of Financial Intermediation, 14(1), pp. 58-85. http://dx.doi.org/10.1016/j.jfi.2004.04.002

James R. B., Gerard C.J., Ross L. (2004). "Bank regulation and supervision: what works best?”, Journal of Financial Intermediation, 13(2), pp. 205-248. http://dx.doi.org/10.1016/j.jfi.2003.06.002

John A. Haslem, Carl A. Scheragavà James P.Bedingfield. (1999). "DEA efficiency profiles of US banks operating internationally", International review of Economics \& Finance, Volume 8, Issue 2, June 1999, Pages 165 - 182.

John Hawkins \& Philip Turner. (1999). "Bank restructuring in practice: an overview”, BIS. 
Klingebiel, D \& G Caprio. (1996). "Bank insolvency: bad luck, bad policy or bad banking”, Annual World Bank conference.

Laurent Quignon. (2006). "European banking restructuring".

Leigh Drake and Maximilian J.B.Hall. (2003). "Efficiency in Japanese banking: An empirical analysis", Journal of Banking and Finance, Volume 27, Issue 5, May 2003, Pages 891- 917

Levonian, M \& Jaffee, Dwight M. (2000). "The structure of banking system in developed and transition economies". EFMA 2000 Athens Meetings.

Margery Waxman. (1998). "A legal framework for systemic bank restructuring”.

Morris Goldstein, Graciela L. Kaminsky, Carmen M. Reinhart. (2000). “Assessing financial vulnerability - An early warning system for emerging markets", Institute for International Economics.

Nguyen Thi Kim Thanh. (2012). "The current situation of Vietnam banking system”, Vietnam Spring Forum, 4/2012, co-hosted by UNDP and Congress Party Commission of Economic

PhanMinh Ngoc. (2012). "Improving the banks' liquidity?" [Online] Available: http://daibieunhandan.vn/default.aspx?tabid=75\&NewsId=243657

Quach ManhHao. (2012). "The weakness of Vietnam banking system nowadays", Journal of economics and Business, Vol. 28.

Timothy J. C., Gary S. F., Carlos D. R. (2008). "The impact of bank supervision on loan growth", The North American Journal of Economics and Finance, 19(2), pp. 113-134. http://dx.doi.org/10.1016/j.najef.2007.10.002

Vo Tri Thanh. (2012). "Financial system restruturing in Vietnam - some policy measures", Vietnam Spring Forum, 4/2012, co-hosted by UNDP and Congress Party Commission of Economic.

Vu Thanh Tu Anh. (2012). "State -Owned - Enterprises in Vietnam”, Vietnam Spring Forum, 4/2012, co-hosted by UNDP and Congress Party Commission of Economic.

William R White. (2008). "Past financial crisis, the current financial turmoil and the need for a new macrofinancial stability framework". 